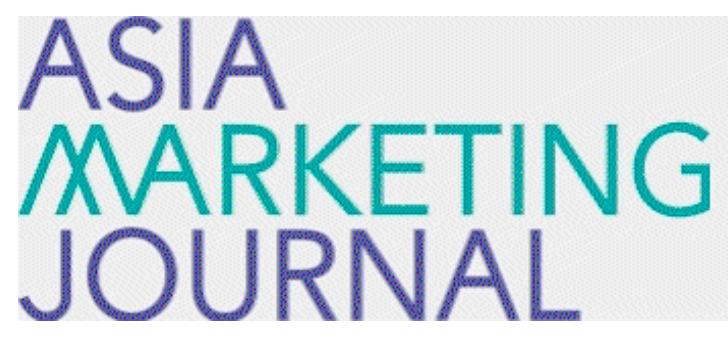

ASIA MARKETING JOURNAL

Volume 15 | Issue 1

Article 4

4-30-2013

\title{
A Comparative Analysis on the Competitiveness of Korean and Japanese Fashion Industry by Applying Generalized Double Diamond Model
}

Mi Young Son

Yokoyama Kenji

Follow this and additional works at: https://amj.kma.re.kr/journal

Part of the Marketing Commons

\section{Recommended Citation}

Son, Mi Young and Kenji, Yokoyama (2013) "A Comparative Analysis on the Competitiveness of Korean and Japanese Fashion Industry by Applying Generalized Double Diamond Model," Asia Marketing Journal: Vol. 15 : Iss. 1 , Article 4.

Available at: https://doi.org/10.53728/2765-6500.1510

This Article is brought to you for free and open access by Asia Marketing Journal. It has been accepted for inclusion in Asia Marketing Journal by an authorized editor of Asia Marketing Journal. 


\title{
A Comparative Analysis on the Competitiveness of Korean and Japanese Fashion Industry by Applying Generalized Double Diamond Model*
}

\author{
Mi Young Son** \\ Yokoyama Kenji***
}

The purpose of this paper is to seek ways to improve the competitiveness of Korea's fashion industry by utilizing the source of competitiveness of Japan's fashion industry, which represents the world's leading countries in terms of fashion, so that Korea can better enter the global fashion market. The study shall first compare the competitiveness of the Japanese and Korean fashion industries by utilizing the generalized double diamond model: second, provide an understanding of what the Japanese fashion industry can offer to Korean fashion industry and companies - that is, understand what the Japanese fashion industry's competitive edge is: and third, study the kind of global competitiveness that Korea's fashion industry must achieve.

To adopt a generalized double diamond model to compare the competitiveness of the Korean and Japanese fashion industries, we selected 31 sub-variables to act as determinants of the model. That is, we extracted 31sub-variables by doing research of literature to analyze national competitiveness of the fashion industries. To measure these 31 sub-variables, secondary data was gathered. We collected data related to each sub-variable from various sources of Korea and Japan. And to calculate the competitiveness index, we took three steps with reference to previous studies.

We found that status of the fashion industry of the two countries as it stands. That is, Japan is an advanced country of which fashion industry is domestic market-oriented while Korea is a small open economy that mainly focuses on the foreign market. Out of 31 proxy variables, Korea's fashion industry shows higher measurements relating to production and export than Japan, but Japan's fashion industry reports higher measurements than Korea in the fields of $R \& D$, design and brand power, the rate of value added, the efficiency of companies and globalization.

In order for Korea's fashion industry to achieve competitiveness in the global market, it should pursue the following development direction. First, it is very difficult for Korea to follow the footsteps of

\footnotetext{
* This paper was written with the support of the 2011 Overseas Training expense of Korea National Open University.

** Department of Clothing and Textile, Korea National Open University, Seoul, Korea, Corresponding Author (pkt2000@knou.ac.kr)

*** College of International Management \& Graduate School of Management, Ritsumeikan Asia Pacific University, Beppu, Japan
} 
the U.S. and Japanese fashion industries that are able to take advantage of economies of scale, because Korea is smaller than those countries. Therefore, in the case of small economies such as Singapore. strengthening of international activities will practically improve domestic determinants that Korea should improve its domestic diamond by enhancing the current competitiveness of its international diamond. In other words, Korea needs to further endeavor to develop and expand global resources and markets as well as improve its competitiveness in terms of $R \& D$, design and brand power, the rate of value-added, and the efficiency of companies. As the Korean fashion industry shows relatively advanced level of information technology and the fashion education system, it has considerable potential to grow. Korea is expected to have a huge growth potential since it has relatively higher level of information technology, fashion education system and activities than those of Japan in both the domestic diamond and international diamond. In particular, a better environment is laid out before Korea to gain competitiveness in the fashion industry due to the recently growing influence of the Korean Wave that Korea is expected to grow as a leader in the Asian market as well as in the global market.

Key words: Korean Fashion Industry, Japanese Fashion Industry, Generalized Double Diamond Model. Competitiveness.

\section{Introduction}

Changes in consumption patterns, introduction of diverse market opportunities, globalization of production and sale, intensifying global competition, complex trade mechanism such as the World Trade Organization (WTO), and free trade agreements (FTAs) in the current domestic and overseas fashion market are encouraging continuous innovation and change among domestic and overseas fashion companies. Fashion companies are seeking ways to modify themselves in order to survive possible reorganization of the domestic and overseas fashion market following the rise of developing nations that has been occurring since the in- troduction of Agreement on Textiles and Clothing of the WTO (former UR Agreement on Textiles and Clothing) in the fashion industry. Countries that lead the fashion industry, such as the U.S., E.U. member countries, and Japan, as well as newly industrialized countries in terms of fashion, such as Korea, are seeking various ways to foster their own fashion industry under such circumstances. As a consequence, domestic and overseas fashion companies have moved their overseas production bases and turned to global sourcing, outward processing. manufacturing and sales networks, global supply chain management (SCM), and global pipelines (Dickerson 1999: 4-5 Jin 2004: 240242 Son et al. 2007: 508). Since the domestic fashion market is saturated with global and 
domestic fashion companies and brands, it is crucial for Korea's fashion industry to participate in the global fashion market.

The purpose of this paper is to seek ways to improve the competitiveness of Korea's fashion industry by utilizing the source of competitiveness of Japan's fashion industry, which represents the world's leading countries in terms of fashion, so that Korea can better enter the global fashion market. The study shall first compare the competitiveness of the Japanese and Korean fashion industries by utilizing the generalized double diamond model: second, provide an understanding of what the Japanese fashion industry can offer to Korean fashion industry and companies - that is, understand what the Japanese fashion industry's competitive edge is: and third, study the kind of global competitiveness that Korea's fashion industry must achieve.

\section{Theoretical Background and Research Proposition}

\subsection{Korean Fashion Industry and Japanese Fashion Industry}

\subsubsection{The Historical Perspective of the Fashion Industry}

According to many mainstream economists' views such as the Flying Geese model (Akamatsu 1962) and the neo-classical view (the World Bank 1993), it has historically been argued that the modern textile industry including garment manufacturing, is suited to early economies and plays a key role in the initial industrialization process, because it is labor intensive but requires a low level of technology (Kelegama 2009: 580). In the eighteenth century, the modern textile industry began with the manufacture of spinning and weaving machines during the industrial revolution in England. In the beginning of the nineteenth century, textile production extended to the rest of Europe and North America along with the mechanization of industries, and in the twentieth century expanded sequentially to East Asian countries such as Japan and the Big Three (Korea, Hong Kong, and Taiwan) (Leseure, Hurreeram, \& Bennett 2009: 618).

Furthermore, the textile complex in major developed countries (the United States, Canada, nations in Western Europe, Japan, and Australia) typically led the industrialization process within each nation. In each country, the sector became quite advanced and competitive as a producer for textile and apparel markets and eventually evolved into full maturity stage. Japan was clearly the early leader in developing its industry and exporting products to other parts of the world. Many East Asian countries followed in Japan's footsteps to become some of the major suppliers in today's international 
textile and apparel markets. Many of these countries (e.g., Hong Kong. South Korea, and Taiwan) have well-developed production and marketing structures and exert a powerful influence on global markets in the sector. Now, however, the Japanese textile industry had changed its focus to capital- intensive synthetic fiber: its fabric producers are still competitive in the international market, although Korea has also tried to move into capital-intensive, high tech, and value-added industries as a result of developing countries such as China, India, and Vietnam rapidly increasing the competitiveness of their fashion industries (Park and Anderson 1991: 545-546 Dickerson 1999: 51-53).

In the twentieth century, the development and expansion of IT and globalization led to the globalization of the long commodity chain, including a number of economic agents- upstream and downstream, which are spread all over the world in the textile industry. In the global commodity chain, collaborative relationships between advanced countries and developing countries have been developed based on a vertical hierarchy: trademark owners and large retailers from developed countries possess the power in the relationships (Hassler 2003: 515-517).

\subsubsection{Similarities and Differences Between Two Countries}

Many scholars (Lee (a) 2003: 359-361 Lee (b) 2003: 433-435) have pointed out that the Korean fashion industry has some similarity with the Japanese fashion industry. This is due to its similarity to the Japanese fashion industry in terms of political, economic, society and cultural background. In addition, the two countries have much in common in terms of consumers' fashion awareness and their purchase behaviors, as well as business practices of fashion companies, due to two countries' similarity in their acceptance process of western style dress and geographic proximity.

In particular, even though there has been a difference in time. Korea and Japan have shown a similar fashion industry development process: both countries first accepted western-style dresses and suits: then adopted tailor-made suits: and most recently both countries have developed a practical apparel market, mass fashion market, high-sense fashion market and global market. Korea and Japan show similarity in terms of their fashion structure: that is, the textile industry still accounts for a large portion in the entire fashion industry in both countries (Lee (a) 2003: 359-360).

Of course, there are some differences between two countries. First of all, Korea and Japan chose different strategies, because the Japanese fashion industry was based on domestic consumption (like the USA) while the Korean fashion industry was export-driven. Secondly, Korea has been strong in the technical aspects of dyeing and processing as well as 
consumer's sensitivity aspects, which are an important factor to the national image and fashion market while Japan far excelled Korea in technical and design capability (Loe(b) 2003: 433-434). Japan's fashion industry has exercised great influence on the global market. Japan is still positioned as a supplier of high-tech textiles, although it is highly dependent on apparel imports. About $82 \%$ of garments consumed in Japan are imported from China, and the rest are imported from Southeast Asian countries and Bangladesh (Samsung design net 2011). Textile production of Korea, which was once one of the mainstays of the Korean fashion industry, decreased after the mid- $1990^{\circ}$ 's due to the improvement of production capability among developing countries and the decrease in import demand. Finally, there is a time gap between the two countries. When the Korean fashion industry was established, it was 15 years behind Japan's. However, as time went by, the time gap between the two countries' fashion industries has narrowed (Lee (a) 2003: 359).

This study aims to seek ways for the Korean fashion market to enter the global fashion market by comparing the global competiveness between Korean and Japanese fashion industry. one of the leading and advanced fashion industries of the world, as the two industries share geological and cultural similarities. By comparing global competitiveness between the two fashion industries, this study seeks to learn what kind of global competitiveness is needed for the Korean fashion industry to become one of the leading fashion industries of the world as well as analyze in detail the global competitiveness of the Korean fashion industry in order to search the essential factors of competiveness needed for Korea to foray into the global fashion market. To make such study possible, Porter's diamond model and the generalized double diamond method that integrates multinational activities were used to compare and analyze the global competitiveness of the two fashion industries.

\subsection{Double Diamond Theory}

\subsubsection{Porter's Diamond Model}

On the basis of a 4-year study of 10 countries, Porter (1990) introduced the diamond model as a new approach to the analysis of national competitiveness. Porter's diamond model systematically incorporates many important variables into a single model, together with the production factor conditions that most traditional theorists employ to explain national competitiveness. Porter's diamond model is composed of endogenous variables and exogenous variables and provides four determinants which act as valuable terms of reference when evaluating national competitiveness: factor conditions, demand conditions, related and supporting industries, and firm strategy. structure, and rivalry. These four components are endogenous variables and 
interrelated. Additionally, here are two exogenous parameters: government and chance events (Moon, Rugman and Verbeke 1998: 136-137 Rugman and D'Cruz 1993: 19-20).

The first category of determinants, factor conditions, includes human, capital and physical resources (basic conditions) as well as the physical and knowledge infrastructure of a country (advanced factor conditions). The second category, demand conditions includes structures of demand in the home market, the size and growth of home demand and the processes through which domestic demand is internationalized. The third category is the role of related and supporting industries in promoting competitiveness through coordination and sharing activities in the value chain. The fourth category comprises firms strategy, structure, and rivalry, such as the ways in which they are managed and choose to compete (Liu and Hsu 2009: 161 Wyk 2010: 58).

Although Porter's diamond model had contributed to the revolutionary development of an explanation on national competitiveness and many studies have been conducted by applying the model, many other studies have pointed out the limitations of Porter's model. The critical weakness of the model originates from Porter's exclusive focus on the construct of a "homebase". In other words, the single diamond does not provide sufficient explanation for the activities of multinational corporations. In addition, Porter's home-based diamond model does not fit in well with small open economies. From the view point of a small nation, which depends to a large extent on foreign markets and also on foreign policy, Porter's view is mainly fixed on a large home base country, and therefore a single diamond needs to integrate and link with the diamonds of other economically stronger countries. As globalization proceeded apace in the 20th century, global multinational enterprises especially have had an important role as an integrating force in the global economy. Thus many studies hold that Porter's diamond model needs to be substantially modified to take into account the current nature of the MNEs by considering not only domestic but also foreign resources. Subsequently, a modification of Porter's model was proposed and is referred to as the double diamond model (DDM) (Moon and Kim 2010: 77 Moon, Rugman and Verbeke 1998; 148 Rugman and D'Cruz 1993: 24-26 Sardy \& Fetscherin 2009: 7).

\subsubsection{Generalized Double Diamond Model}

Rugman and D'Cruz (1993) introduced the double diamond model linking the domestic diamond of each country to that of a relevant 'triad', thus incorporating the international context of national competitiveness. Furthermore they proposed that global managers consider both domestic and foreign diamonds to survive and grow in an increasingly globalized market (Rugman and D'Cruz 1993: 29-31 Moon and 
Kim 2010: 77).

Although D'Cruz's North American diamond framework fits Canada and New Zealand well, it may not fit other small nations such as Korea and Singapore. Firms from small countries or operations of MNEs, which are engaged in both domestic and global competition for resources and markets, are likely to be concerned more with global than domestic industrial structure. The linkage with other countries' diamonds can impact the domestic diamond. Thus, Moon et al (1995: 1998) generalized the double diamond model (generalized double diamond model, GDDM) to fit all small open economies by formally integrating the multinational activities demonstrated as the difference between the domestic diamond and the international diamond (Liu and Hsu 2009: 162 Moon, Rugman and Verbeke 1998: 148).

In the generalized double diamond model, Moon et al. (1998) define national competitiveness as the capability of enterprises engaged in value-added activities in a specific industry in a particular country to sustain this added-value over long periods of time in spite of international competition. Therefore, sustained valueadded activities in specific industries in a particular country may result from both domestically and foreign-owned enterprises. The international diamond represents the national competitiveness determined by domestic and international parameters. These multinational activities are composed of outbound and in- bound foreign direct investment (Liu and Hsu 2009: 162-163 Moon, Rugman and Verbeke 1998: 138-139).

The DDM has proven to be more useful for making global comparisons. It has three important extensions to Porter's single diamond model: (1) the model clearly incorporates multinational activities: (2) the model is able to operationalize the competitiveness paradigm and a comparison of the size and shapes of the domestic and international diamonds shows major strategic differences: (3) it includes government as an important variable that influences the four determinants of the Diamond Model. In order to assess global competitiveness, both domestic and international determinants have to be taken into account (Sardy and Fetscherin 2009: 7).

\subsubsection{Application of Double Diamond Model}

The double diamond model and the generalized double diamond model have been mainly applied to comparative analyses of the competitiveness of the two industries.

Birdwell and Kuo (2006), in discussing the computer industry in China and Taiwan, outlined a single "Diamond" for each country, but also a "Double Diamond" for the greater China, i.e. two countries or one nation with two interconnected regions. Moon et al (1998) proves the validity of the GDDM through the empiri- 
cal study of Korea and Singapore. Originally, the two economies were chosen due to Porter's inappropriate prediction about these two economies based on the single diamond. After the ten-year of the Asian Financial Crisis in 1997, Kim and Moon (2010) compared and contrasted the competitiveness of Korea and Singapore over the preceding ten years. Liu and Hsu (2009) compared the competitiveness of the economies of Taiwan and Korea. The comparisons between each pair of countries were based on the average values of the data over five years (2000-2004). They applied a generalized double diamond model approach to analyze the overall competitiveness of these small open economies. Wyk (2010) did not compare two industries or economies, but instead investigated the national competitiveness of Botswana in the global diamond industry. A double diamond framework was developed to explore Botswana's competitiveness, and to initiate change in the country's national competitiveness strategy.

Moon and Lee (2004) tried to clarify the issue of the competitiveness of Samsung Electronics and Sony using the generalized double diamond model and also suggested the main factor determining the competitiveness of multinational firms in the global market. Kim et al. (2006) and Son et al. (2007) had different methods and procedures for collecting data, but both applied the generalized double-diamond theory to compare the competitiveness of the Chinese and Korean fashion industries in order to investigate the competitive advantage of the Korean fashion industry and build an entry strategy for the Chinese fashion market. Sardy and Fetscherin (2009) compared industry competitiveness of emerging automotive manufacturing industries in China, India, and South Korea by using the double diamond model.

\section{The Analysis of Generalized Double Diamond Model}

\subsection{Determination of Variables and Descriptive Data}

To adopt a generalized double diamond model to compare the competitiveness of the Korean and Japanese fashion industries, we selected 31 sub-variables to act as determinants of the model. That is, we extracted 31sub-variables by doing research of literature (Jin 2004 Jin and Moon $2006 \mathrm{Kim}$ et al. $2006 \mathrm{Liu}$ and Hsu 2009 Moon and Kim 2010 Moon and Lee 2004 Shafaei 2009 Son et al. 2007) to analyze national competitiveness of the fashion industries. To measure these 31 sub-variables, secondary data was gathered. We collected data related to each sub-variable from various sources of Korea and Japan.

As shown in 〈Table 1), according to the model, the four determinants are: factor conditions, demand conditions, related and sup- 
〈Table 1) Four Factor Conditions of Diamond Model and Proxy-Variables, Measurements

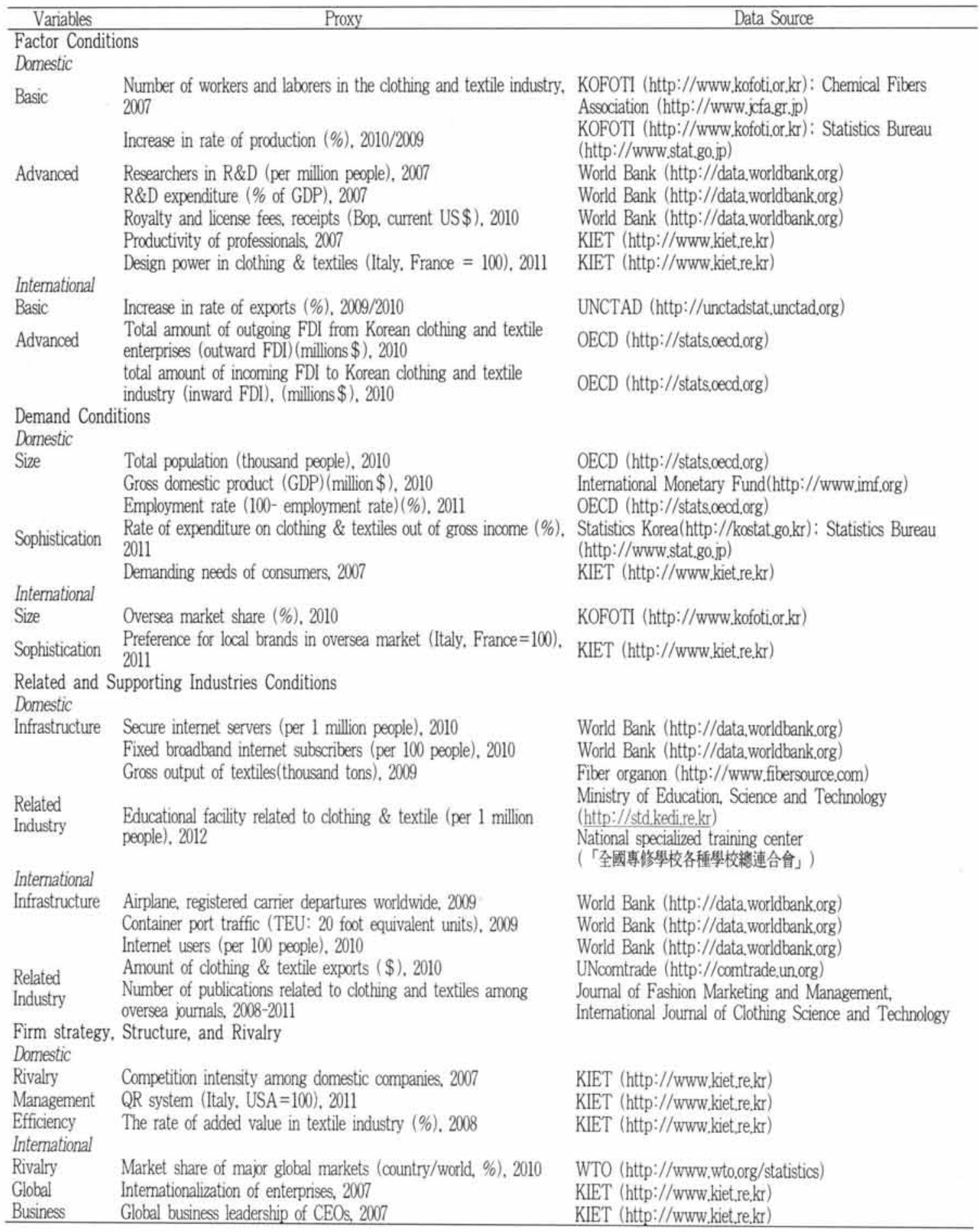


porting industries, and firm strategy, structure and rivalry. Each condition is divided into domestic and international variables.

Each sub-variable of each determinant selected for following grounds.

\subsection{Factor Conditions}

Factor conditions, which refer to the nation's position in factors of production that was necessary to compete in a given industry, are classified into basic factors and advanced factors. The former refer to natural resources, location, unskilled labor, debt capital, while the latter indicates modern social infrastructure and highly educated professionals (Porter 1990: 71 Moon and Kim 2010: 80-81).

Porter(1990: 77) argues that advanced factors are now the most significant factors for competitive advantage, and the institutions required to create truly advanced factors(such as educational programs) themselves require sophisticated human resources and/or technology. Liu \& Hsu (2009: 165) also conclude that the scale and the results of $R \& D$ investment are the most fundamental elements for determining innovation.

Advanced or specialized factors are necessary for more sophisticated forms of competitive advantage in fashion industry. New competitive factor conditions in apparel industry lie in advanced or specialized factors, such as skilled human resources (e.g. creative designers) and production and process technology. These new sources of competitive factors can be easily observed in the most advanced fashion countries such as France, Italy and the US (Jin and Moon 2006: 197).

For international factor conditions, Korea already relocated most of their labor-intensive production operation to Southeast Asian countries and China because wages had rapidly increased in Korea. However Korea still needs to attract investment from multinational firms from advanced countries, obtain modern technologies from them and ultimately improve domestic factor conditions through R\&D collaboration with those firms. Therefore FDI inflow/ outflow are important international strategies for improving national competitive advantage (Liu and Hsu 2009: 165 Moon and Kim 2010: 81).

\subsection{Demand Conditions}

Demand conditions, which refer to the nature of the home-market demand for an industry's product or service (Porter 1990: 71), distinguish the size and the sophistication of demand. The size of domestic demand in fashion industry may be important to national advantage from the perspective of economic scale and learning speed, but the presence of sophisticated, demanding buyers is more important in the fashion industry, as domestic consumers demand for creative designs, services, or brands strengthens national competitiveness. Those consumers' so- 
〈Table 2〉 Descriptive Data for Factor Conditions

\begin{tabular}{|c|c|c|c|c|}
\hline & Variables & Proxy & Korea & Japan \\
\hline \multicolumn{5}{|l|}{ Domestic } \\
\hline \multirow[t]{2}{*}{ Basic } & \multirow[t]{2}{*}{ Scale } & $\begin{array}{l}\text { Number of workers and laborers in the clothing } \\
\text { and textile industry, } 2007\end{array}$ & 87,778 & 258,600 \\
\hline & & Increase in rate of production (\%), 2010/2009 & 108.9 & 102.4 \\
\hline \multirow[t]{5}{*}{ Advanced } & \multirow[t]{3}{*}{$R \& D$} & Researchers in R\&D (per million people), 2007 & 4627 & 5573 \\
\hline & & R\&D expenditure (\% of GDP), 2007 & 3.2 & 3.4 \\
\hline & & $\begin{array}{l}\text { Royalty and license fees, receipts (Bop, current } \\
\text { US } \$ \text { ), } 2010\end{array}$ & $3,145,800,000$ & $26,680,317,334$ \\
\hline & \multirow[b]{2}{*}{$\begin{array}{l}\text { Technical } \\
\text { Power }\end{array}$} & Productivity of professionals, 2007 & 10.9 & 12.6 \\
\hline & & $\begin{array}{l}\text { Design power in clothing \& textiles (Italy, } \\
\text { France }=100 \text { ), } 2011\end{array}$ & 60 & 80 \\
\hline \multicolumn{5}{|c|}{ International } \\
\hline Basic & Oversea Sale & Increase in rate of exports (\%), 2009/2010 & 144 & 133 \\
\hline \multirow[t]{2}{*}{ Advanced } & $\begin{array}{l}\text { Oversea } \\
\text { Investment }\end{array}$ & $\begin{array}{l}\text { Total amount of outgoing FDI from Korean } \\
\text { clothing and textile enterprises (outward FDI) } \\
\text { (millions \$), } 2010\end{array}$ & 362.8 & 380.6 \\
\hline & & $\begin{array}{l}\text { Total amount of incoming FDI to Korean } \\
\text { clothing and textile industry (inward FDI), } \\
\text { (millions \$). } 2010\end{array}$ & 354.9 & 683.9 \\
\hline
\end{tabular}

Sources: KOFOTI (http://www.kofoti.or.kr): Japan Chemical Fibers Association (http://www.jcfa.gr.jp): Statistics Bureau (http://www.stat.go.jp): World Bank (http://data.worldbank.org): KIET (http://www.kiet.re.kr). "Globalization Divers of Industry and Analysis of Nation's Competitiveness": KIET (http://www.kiet,re.kr). "Fundamental analysis of the textile industry": UNCTAD (http://unctadstat.org): OECD (http://stats.oecd.org). FDI outflows/FDI inflows in textile and wearing apparel industry

phistication and needs are also related to fashion buying behavior such as expenditures and frequency of purchase. Branding in the apparel industry is even more critical, since differentiation and evaluation of items often depends on the brand of the items (Jin and Moon 2006: 198 Kim et al, 2006: 1357 Son et al, 2007: 512).

Small open economies such as Korea have relatively small domestic markets, and it is necessary to search for foreign markets to secure economies of scale. Firms from these kinds of economies cannot limit their business scope to the domestic markets: they must try to export their goods abroad. Hence, overseas market scale as well as preference for local brands in overseas market scan be critical proxies for the complexity of international demand (Liu and Hsu 2009; 166).

\subsection{The Related and Supporting Industry}

Related and supporting industries refer to the presence or absence in the nation of supplier 
〈Table 3〉 Descriptive Data for Demand Conditions

\begin{tabular}{|c|c|c|c|c|}
\hline & Variables & Proxy & Korea & Japan \\
\hline \multicolumn{5}{|l|}{ Domestic } \\
\hline \multirow[t]{3}{*}{ Size } & Market Scale & Total population (thousand people), 2010 & 50,516 & 127.510 \\
\hline & & Gross domestic product (GDP) (million \$), 2010 & 986 & 5,391 \\
\hline & & Employment rate (100-employment rate) (\%), 2011 & 96.9 & 95.4 \\
\hline \multirow[t]{2}{*}{ Sophistication } & $\begin{array}{l}\text { Consumer } \\
\text { Sophistication }\end{array}$ & $\begin{array}{l}\text { Rate of expenditure on clothing \& textile out of } \\
\text { gross income }(\%), 2011\end{array}$ & 4 & 2 \\
\hline & & Demanding needs of consumers & 11.2 & 9.9 \\
\hline \multicolumn{5}{|l|}{ International } \\
\hline Size & Oversea market Scale & Oversea market share (\%), 2010 & 2 & 1.2 \\
\hline Sophistication & $\begin{array}{l}\text { Consumer } \\
\text { Sophistication }\end{array}$ & $\begin{array}{l}\text { Preference for local brands in oversea market } \\
\text { (Italy, France }=100 \text { ), } 2011\end{array}$ & 50 & 90 \\
\hline
\end{tabular}

Sources: OECD (http://stats.oecd.org): International Monetary Fund (http://www.imf.org): Statistics Korea (http:// kostat.go.kr): Statistics Bureau (http://www.stat.go.jp): KIET (http://www.kiet.re.kr). "Globalization Divers of Industry and Analysis of Nation's Competitiveness": KOFOTI (http://www.kofoti,or.kr): KIET (http:// www.kiet.re.kr). "Fundamental analysis of the textile industry"

industries and related industries that are internationally competitive (porter 1990: 71). These industries consist of firms on the upstream and downstream, related industries and other supporting industries. Additionally, these industries should include not only infrastructure such as transportation and communication (Moon and Kim 2010; 82), but also industries which help and expedite other industries within the economy, by providing benefits such as innovation, upgrading, information flow, and shared technology development which create advantages in downstream industries (Shafaei 2009: 23 Ozgen 2011: 68).

In today's global apparel environment, which requires global market, global sourcing and global supply chain, efficient strategies of transportation and communication are necessary. That is, global chain management and information technology are more important than supplies such as raw materials. For example, Liz Claiborne Inc. sources from as many as 31 different countries using 240 factories. Therefore, coordinating production and efficient communication with suppliers have become critical (Jin and Moon, 2006: 198-199). Also, industries related to fashion, including textile industries and education and knowledge industry are also important for building a competitive advantage (Kim et al. 2006: 1357 Son et al. 2007: 513).

For small open economies facing severe competition, such as Korea, backup from domestic related and supporting industries is simply not enough: more synergy with and expansion into related and supporting international industries are very necessary (Liu and Hsu 2009; 167). 
〈Table 4〉 Descriptive Data for the Related and Supporting Industry Conditions

\begin{tabular}{|c|c|c|c|c|}
\hline & Variables & Proxy & Korea & Japan \\
\hline \multicolumn{5}{|l|}{ Domestic } \\
\hline \multirow[t]{3}{*}{ Infrastructure } & Transportation & Roads, paved ( $\%$ of total roads), 2007 & 78.3 & 79.6 \\
\hline & Communication & Secure internet servers (per 1 million people), 2010 & 1,140 & 650 \\
\hline & & $\begin{array}{l}\text { Fixed broadband internet subscribers (per } 100 \\
\text { people), } 2010\end{array}$ & 36 & 27 \\
\hline \multirow[t]{2}{*}{$\begin{array}{l}\text { Related } \\
\text { Industry }\end{array}$} & Related Industry & Gross output of textiles (thousand tons), 2009 & 1,410 & 720 \\
\hline & & $\begin{array}{l}\text { Educational facilities related to clothing \& } \\
\text { textiles(per } 1 \text { million people), } 2012\end{array}$ & 1.70 & 1.98 \\
\hline \multicolumn{5}{|l|}{ International } \\
\hline \multirow[t]{3}{*}{ Infrastructure } & Transportation & $\begin{array}{l}\text { Airplanes, registered carrier departures } \\
\text { worldwide. } 2009\end{array}$ & 256,160 & 641,913 \\
\hline & Communication & $\begin{array}{l}\text { Container port traffic (TEU: } 20 \text { foot } \\
\text { equivalent units), } 2009\end{array}$ & 16.053 .629 & $16,285,918$ \\
\hline & & Internet users (per 100 people), 2010 & 83 & 79 \\
\hline \multirow[t]{2}{*}{$\begin{array}{l}\text { Related } \\
\text { Industry }\end{array}$} & Related Industry & Amount of clothing \& textile exports ( $\$$ ) & $13,984,209,799$ & $9,034,793,883$ \\
\hline & & $\begin{array}{l}\text { Number of publications related to clothing and } \\
\text { textiles among oversea journals, 2008-2011 }\end{array}$ & 20 & 9 \\
\hline
\end{tabular}

Sources: World Bank (http://data,worldbank.org): Fiber Organon (http://www.fibersource.com): Ministry of Education, Science and Technology (http://std.kedire.kr): National Specialized Training Center ( r全國專修學校各種學校總 連合會」): UNcomtrade (http://comtrade.un.org): http://search,proquest.com/publication (Journal of fashion marketing and management / International journal of clothing science and technology)

In today's global environment infrastructure for international transportation and communication for international business is important (Moon et al. 1998: 143) and actually it is necessary for those countries to enter the global market (Yeu et al. 2013: 263 Lee et al 2010: 96)

\subsection{Firm Strategy, Structure, and Rivalry}

Firm strategy, structure, and rivalry refer to the conditions in the nation governing how companies are created, organized, and managed, and the nature of domestic rivalry (Porter 1990: 71). That is, the establishment, organization and management of firms and the condition of the competitors are all important parts of national competitiveness, and vary with the strategy, structure, and rivalry of each country (Liu and Hsu 2009: 167).

One important source of competitive advantage in the apparel industry has been high quality design. In context of global competition, agility, which is a new and different source of 
〈Table 5〉 Descriptive Data for Firm Strategy, Structure, and Rivalry Conditions

\begin{tabular}{lllrr}
\hline \multicolumn{1}{c}{ Variables } & \multicolumn{1}{c}{ Proxy } & Korea & Japan \\
\hline $\begin{array}{l}\text { Domestic } \\
\text { Rivalry }\end{array}$ & Market Competition & Competition intensity among domestic companies, 2007 & 10.5 & 8.7 \\
Management & Agility & QR system(Italy, USA=100), 2011 & 60 & 90 \\
Efficiency & High design Quality & The rate of added value in textile industry(\%), 2008 & 24.2 & 36.3 \\
International & & & & \\
Rivalry & Market Competition & Market share of major global markets(country/world, & 2.1 & 1.3 \\
Global & Global Networking & Internationalization of enterprises & 10.4 & 12.3 \\
Business & Global Challenge & Global business leadership of CEOs, 2007 & 10.9 & 12.9 \\
\hline
\end{tabular}

Sources: KIET (http://www.kiet,re.kr), "Globalization divers of Industry and analysis of nation's competitiveness" ; KIET(http://www,kiet,re,kr). "Fundamental analysis of the textile industry" : WTO(http://www.wto,org/statistics)

competitive advantage, should be added along with high quality design. The fashion industry is characterized by extensive and diverse sources of uncertainty due to fluctuating demands, seasonal changes, and variation in style preferences. In response to market instability, apparel firms must react rapidly; thus 'agility' has become a means of achieving competitive advantage. In the case of Zara, it takes less than two weeks for seasonal items to get from the design room to a store. Design-to-delivery is as much as 12 times faster for Zara than for its competitors (Jin 2004: 240 Jin and Moon 2006: 199).

The fashion industry has certain defining features, such as the long global commodity chain, which involves many global economic agents such as fiber, textile, fabric and raw material suppliers: cutting, sewing and finishing process: design, buying, marketing brands, retailers and traders: transportation; and warehouses.
These economic agents are generally spread all over the world. Therefore, maintaining efficient global network of both local and oversea sources and continuously upgrading internal capabilities are critical to succeed in the global fashion industry (Jin 2004: 241 Kim et al. 2006: 1358 Shafaei 2009: 27).

\section{Empirical Results of the Diamond Test}

\subsection{Calculating Scores and Drawing the Diamond}

To calculate the competitiveness index, we took three steps with reference to previous studies (Moon et al. 1998 Moon and Lee 2004 Liu and Hsu 2009 Sardy and Fetscherin 2009 Moon and 
Kim 2010). Before describing the steps, the structure of the competitiveness index must to be outlined. The competitiveness index is the result of the calculation of the data for domestic and international variables, consisting of four conditions. Each condition is measured by several sub-variables (proxy variables). First, for each proxy variable, the maximum score "100" is given to the country with the higher value, and a relative ratio in terms of a percentage is given to the country that has the lower value. That is, the score of the country with the higher value is " 100 ", and the score of the country with the lower value was calculated by dividing the lower value by the higher value. For example, with respect to increase in rate of exports', which is one of proxy variables of international factor conditions, the values of Korea and Japan are 144 and 133. The maximum score (100) is given to Korea, Japan's score is $92.36(=133 / 144 * 100)$.

Second, for each domestic (or international) variable of a condition, which contains more than one sub-variable, impartial weights are given to each sub-variable. For example, for the international variable of factor conditions, which contains three sub-variables (increase in rate of exports, outward FDI, inward FDI), the Korea's score of international factor condition is $82.41(=100 / 3+95.32 / 3+51.90 / 3)$.

Third, a global diamond is constructed by adding the international competitiveness index to the domestic competitiveness index for each condition. For instance, Korean domestic factor condition is 69.08. By adding the international competitiveness index 82.41 to this score, and then simply averaging the sum, the Korean global diamond for factor condition is determined to be 75.74 .

Competitiveness indices in $\langle$ Table 6$\rangle$ are the result of the calculation of descriptive data for factor conditions 〈Table 2〉, demand conditions $\langle$ Table 3〉, RSI conditions 〈Table 4〉, and SSR conditions $\langle$ Table 5$\rangle$, using the steps of calculation above.

\subsection{Domestic Variables of the Diamond Model}

〈Figure 1〉 shows the empirical results of the domestic diamond. According to the domestic diamond, the Japanese fashion industry surpasses the Korean fashion industry in all factors except for related and supporting industries conditions. This means that except for the RSI determinant, the Japanese fashion industry is more competitive in all domestic determinants.

We can find several important implications when the measurements of the proxy variables are closely examined together. First of all, the domestic diamonds of Japan and Korea demonstrate that Japan has saturated fashion industry characteristics of developed countries while Korea shows fashion industry characteristics displayed by NICs. Moreover, when examining the results of the comparative research of the 
$\langle$ Table 6〉 Competitiveness Index of the Diamond Model

\begin{tabular}{lcc}
\hline & Korea & Japan \\
\hline Factor Conditions & & \\
Domestic Value & 69.08 & 99.15 \\
International Value & 82.41 & 97.45 \\
International Diamond (Domestic + International) & 75.74 & 98.30 \\
Demand Conditions & & \\
Domestic Value & 71.58 & 87.37 \\
International Value & 77.78 & 80.00 \\
International Diamond (Domestic + International) & 74.68 & 83.68 \\
Related and Supporting Industries Conditions & & \\
Domestic Value & 96.85 & 76.41 \\
International Value & 87.70 & 81.17 \\
International Diamond (Domestic + International) & 92.27 & 78.79 \\
Firm Strategy, Structure, and Rivalry Conditions & & \\
Domestic Value & 77.78 & 94.29 \\
International Value & 89.68 & 87.30 \\
International Diamond (Domestic + International) & 83.73 & 90.79 \\
\hline
\end{tabular}

competitiveness of Korea and China's fashion industries pursuant to the same method (Kim et al 2006: 29 Son et al 2007: 20), Korea produced more competitive determinants than China except for factor conditions. In other words, the domestic diamond results of Japan-Korea and Korea-China clearly show the fundamental differences between advanced nations and NICS, that is, the differences in the degree of industrialization of the fashion industry.

Secondly, Korea reports higher measurements relating to production and exporting, but Japan excels Korea in R\&D, technology and design ability, the rate of value added and the efficiency of companies. That is, Japan's fashion industry has already changed its focus to capi- tal-intensive and technology-intensive industry while Korea's fashion industry is trying to follow the advanced countries' fashion industry.

Lastly, however, something remarkable appeared regarding Korea's information technology infrastructure: Japan shows a lower measurement than Korea in terms of information technology infrastructure. As information technology has become the foundation of the development for almost every field of industry in the $21^{\text {st }}$ century, the prospect of the Korean fashion industry seems bright. Just as mentioned by Jin (2006: 202), with the growing power of design and the power of culture with the recent Korean Wave, we believe Korea will grow to become a leader that may even sur- 
〈Figure 1〉 Domestic Diamond of the Korean Fashion Industry and Japanese Fashion Industry

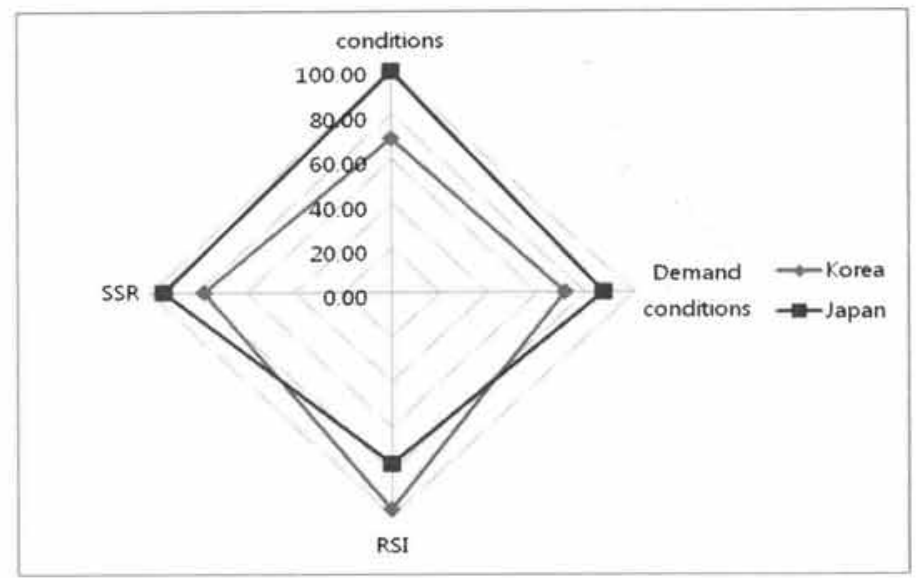

pass Japan in the fashion industry.

\subsection{International Variables of the Diamond Model}

〈Figure 2〉 shows the empirical results of the international diamond. According to the international diamond, the Japanese fashion industry is more competitive in all determinants of the international diamond except for related and supporting industries conditions, identically to the domestic diamond. When comparing the Korean and Japanese international diamond shapes to the domestic diamond shapes, the international diamonds are more similar than the domestic one. That means the Korea fashion industry is almost as competitive as the Japan fashion industry.

We can find several important implications when the measurements of the proxy variables are closely examined together. First of all, as shown by the result of the domestic diamond, Korea shows fashion industry characteristics of NICs so Korea reports higher measurements relating to production than Japan. However, Japan shows fashion industry characteristics of an advanced country and reports higher measurements than Korea in the fields of inward and outward FDI, brand power in the foreign market, and corporate globalization. As found from the result of the domestic diamond, however. Japan shows lower measurements than Korea in the fields of information technology and education.

International diamond can be understood as the globalization index of fashion industry for each nation (Son et al 2007: 17), and in the case of Korea, it is important for the Korean fashion industry to focus on global resources and markets as well as the level of globalization of companies as well as the nation itself to develop its competitiveness since the scale of 
$\langle$ Figure 2〉 International Diamond of Korea Fashion Industry and Japan Fashion Industry

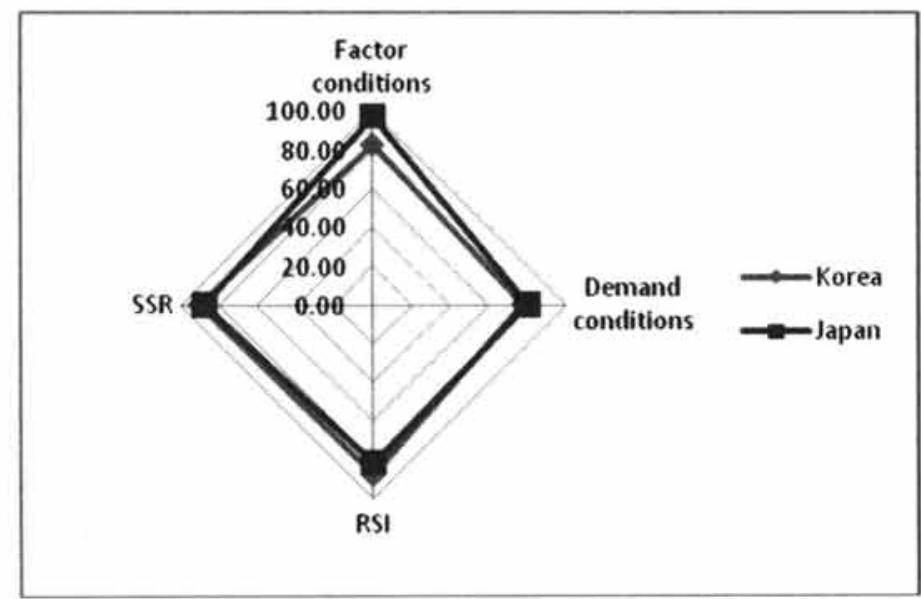

Korea's economy is relatively small (Moon 1998: 7). It is encouraging that the international diamond of Korea is similar to that of Japan, and Korea's higher competitiveness in information technology and education shows it is possible for Korea to improve the competitiveness of its fashion industry.

\subsection{Competitiveness Index of the Diamond Model}

〈Figure 3 〉 shows the empirical results of the global diamond. All scores for the global diamond are calculated as the average sum of the scores from the domestic and international diamonds. Looking into the domestic and international diamonds separately and regarding determinants of each country's competitiveness, competitiveness can be more clearly shown and explained through the global diamond, which synthesizes domestic and international diamonds.
The Japanese fashion industry is more competitive in all determinant of global diamond except for related and supporting industries conditions, just as it was with the domestic and international diamonds.

Comparison of the national competitiveness of Korea and Singapore by Moon and Kim (2010: 85) shows similar results to this study. That is, Korea has achieved remarkable growth in related and supporting conditions and this achievement is mainly attributable to the development of its world-class IT infrastructure and transportation sector. However, Korea needs to be more concerned about the improvement of factor condition as well as demand conditions. Therefore, Korea needs to focus on improving factor conditions as well as demand conditions, firm strategy, structure and rivalry conditions in order to gain global competitiveness in the fashion industry. 
〈Figure 3〉 Global Diamond of Korea Fashion Industry and Japan Fashion Industry

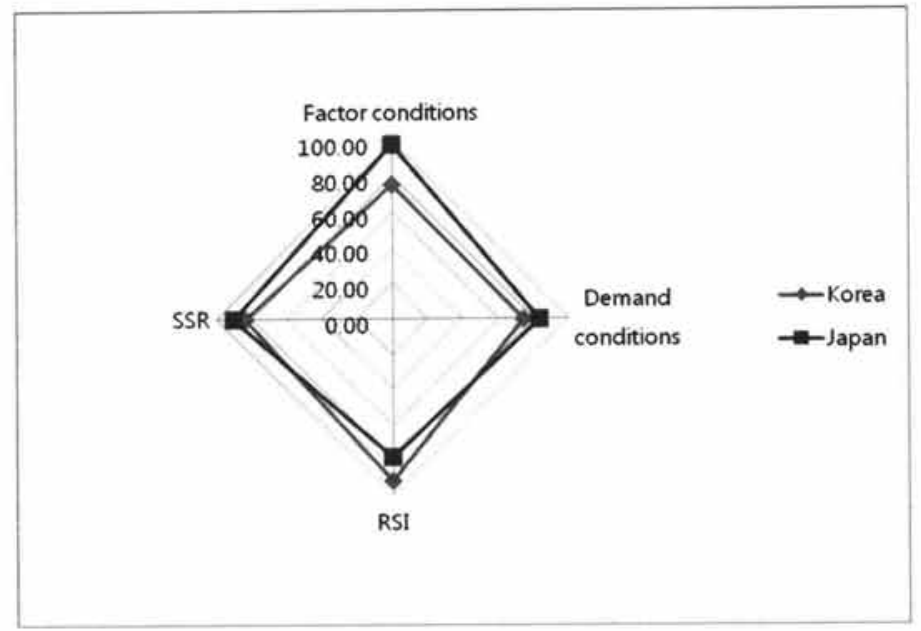

\section{Conclusion and Limitations}

\subsection{Implications}

This study compares the Korean fashion industry with the Japanese fashion industry, which is one of the leading fashion industries in the world and at the same time shares many geological and cultural similarities with Korea, by using the generalized double diamond model and aims to find out what kind of global competitiveness is needed for Korea to become one of the leaders in the world fashion industry as well as analyze Korean fashion industry's current global competitiveness.

That is, the Japanese fashion industry is that of an advanced country which led the export of textiles and apparel products in the mid1960s following the U.S. and Europe. On the other hand, Korea's fashion industry is that of NICs which led the global export of textiles and apparel products in the 1980s among East Asian countries following Japan. In addition, Japan is an advanced country in which the fashion industry is domestic market-oriented while Korea is a small open economy that focuses more on the foreign market. The result of this study shows the status of the fashion industry of the two countries as it stands. Out of 31 proxy variables, Korea's fashion industry shows higher measurements relating to production and export than Japan, but Japan's fashion industry reports higher measurements than Korea in the fields of $R \& D$, design and brand power, the rate of value added, and the efficiency of companies and globalization.

In order for Korea's fashion industry to achieve competitiveness in the global market, it should pursue the following development direction. 
First, it is very difficult for Korea to follow the footsteps of the U.S. and Japanese fashion industries that are able to take advantage of economies of scale, because Korea is smaller than those countries. Therefore, just as pointed out by Moon and Kim (2010: 86), in the case of small economies such as Singapore, strengthening of international activities will practically improve domestic determinants that Korea should improve its domestic diamond by enhancing the current competitiveness of its international diamond. In other words, Korea needs to further endeavor to develop and expand global resources and markets as well as improve its competitiveness in terms of $R \& D$, design and brand power, the rate of value-added, and the efficiency of companies.

As the Korean fashion industry shows relatively advanced level of information technology and the fashion education system, it has considerable potential to grow. Korea is expected to have a huge growth potential since it has relatively higher level of information technology, fashion education system and activities than those of Japan in both the domestic diamond and international diamond. In particular, a better environment is laid out before Korea to gain competitiveness in the fashion industry due to the recently growing influence of the Korean Wave that Korea is expected to grow as a leader in the Asian market as well as in the global market just as Lee (2003: 362) mentioned.

\subsection{Limitations of the Study and Suggestions for Further Studies}

This study is meaningful in that it uses the generalized double diamond model to visualize a comparison of the Korean fashion industry (based on small, open economy) with the Japanese fashion industry (based on an advanced, developed country). The study, however, can be supplemented and improved in several ways. Above all, it uses secondary data to obtain the measurements of variables. However, when it comes to the measurement of firm strategy, structure and rivalry conditions, obtaining indepth data through corporate surveys is critical. In addition, given that this study uses secondary data from the years between 2007 and 2011, the scope of the data is somewhat broad, although previous studies (Liu and Hsu 2009 Moon and Kim 2010 Moon and Lee 2004) used data stretching over four to five years. In particular, as the fashion industry changes faster than any other industry in the global commodity chain, the scope of secondary data should be narrowed to less than three years.

Second, this study uses the generalized double diamond model as a framework. The generalized double diamond model is a model suggested by Moon et al. (1998) to compare competitiveness of small open economies. Therefore, considering that this study is to compare the fashion industry of an advanced country (i.e., Japan) and a small open economy (i.e., Korea). 
generalizing the results of the global diamond by utilizing the generalized double diamond model would be impracticable. Thus, it is necessary to develop a model to be used to compare the competitiveness of countries with different sizes and in different stages of development.

〈Received November 18. 2012〉

〈1st Revised January 21. 2013〉

〈2nd Revised February 22. 2013〉

〈Accepted February 28. 2013〉

\section{References}

Bridwell, Larry and Kuo, Chun-Jui. (2006), "An analysis of the computer industry in China and Taiwan using Michael Porter's determinants of national competitive advantage," Competitiveness Review, 15(2). 116-120.

Cho, Dong-Sung, Moon, Hwy-Chang, and Kim, Min-Young. (2009), “Does One Size Fit All? A Dual Double Diamond Approach to Country-Specific Advantages," Asian Business \& Management, 8(1), 83-102.

Dickerson, Kitty G. (1999), "Textiles and Apparel in the Global Economy," New Jersey: Prentice Hall.

Dunning, John H. (2003), “The role of foreign direct investment in upgrading China's competitiveness," Journal of International Business and Economy, 4(1), 1-13,
Hassler, Markus, (2003), “The Global Clothing Production System: Commodity Chains and Business Networks," Global Network. 3(4), 513-531.

Jin, Byoungho. (2004), "Apparel Industry in East Asian Newly Industrialized Countries: Competitive Advantage, Challenge and Implications," Journal of Fashion Marketing and Management, 8(2), 230-244.

Jin, Byoungho and Moon, Hwy-Chang. (2006), "The Diamond Approach to the Competitiveness of Korea's Apparel Industry: Michael Porter and Beyond," Journal of Fashion Marketing and Management, 10 (2). 195-208.

Kelegama, Saman. (2009), "Ready-Made Garment Exports from Sri Lanka," Journal of Contemporary Asia, 39(4), 579-596.

Kim, Mi-Jung, Kwak, Da-Ra, and Lee, Yu-Ri. (2006), "Analysis of International Competitiveness of Apparel Industry in Korea and China Based on the Generalized Double Diamond Model," Journal of the Korean Society of Clothing and Textiles, 30(9/10). 1354-1365.

Lee(a), Dong-Gun. (2003), “The Suggestion for Korean Textile and Fashion Industry: A Proposal from the comparison with the structure of Korea and Japan," Journal of Korean Society Clothing Industry, 5(5), 433-437.

Lee(b), Ho-Jeong.(2003), "A Study on Marketing Strategy through Comparison of 
Fashion Industry Development Process between Korean and Japan," Journal of Korean Society Clothing Industry, 5(4). 351-362.

Lee Jin Yong, Kim Chung Koo and Joo Young Hyuck. (2010), “Lotte Shopping's Marketing Strategy for Achieving the Goal of Becoming a Global Leader," Asia Marketing Journal, 12(1), 81-101.

Lee, Kyung-Hee. (2008), "Change of Japanese Street Fashion after the Second World War," Journal of Korean Society Clothing Industry, 10(1), 30-39.

Leseure, Michel, Hurreeram, Dinesh. \& Bennett, David. (2009). "Playing Catch-up with China: Challenges and Strategies for Smaller Developing Countries," Technology Analysis \& Strategic Management, 21(5), 617-637.

Liu. Day-Yang and Hsu, Hsin-Fang. (2009), "An International Comparison of Empirical Generalized Double Diamond Model Approaches to Taiwan and Korea," Competitiveness Review: An International $\mathrm{Bu}^{-}$ siness Journal, 19(3), 160-174.

Moon, Hwy-Chang, Rugman, Alan M. and Verbeke, Alain. (1995), "The generalized double diamond approach to international competitiveness," Research in Global Strategic Management, 5, 97-114.

Moon, Hwy-Chang, Rugman, Alan M, and Verbeke, Alain. (1998), “A generalized double diamond approach to the global competitiveness of Korea and Singapore," Inter- national Business Review. 7, 135-150.

Moon, Hwy-Chang and Lee, Donghun. (1999), "Location Advantage of Korea for the Telecommunication Industry: The Generalized Double Diamond Approach," International Management Research, 10(1), 107-127.

Moon, Hwy-Chang and Kim, Ji Youn.(2010). "Comparing the Competitiveness of Korea and Singapore after Ten Years of Asian Economic," The review of Business History. 25(1), 75-91.

Ozgen, Eren. (2011). "Porter's Diamond Model and Opportunity Recognition: a Cognitive Perspective," Academy of Entrepreneurship Journal, 17(2), 61-76.

Porter, Michael E. (1990), “The Competitive Advantage of Nations," New York: The Free Press.

Park. Young-Il and Anderson, Kym. (1991). "The Rise and Demise of Textile and Clothing in Economic Development : the Case of Japan," Economic Development and Cultural Change, 39(3), 531-548.

Rugman, Alan M., and D'Cruz, Joseph R. (1993), "The "Double Diamond" Model of International Competitiveness: the Canadian $\mathrm{Ex}^{-}$ perience," Management of International Review. 33(2), 17-39.

Ryan, R. (1990), "A grand disunity," National Review (9 July).

Shafaei, Rasoul. (2009), “An Analytical Approach to Assessing the Competitiveness in the Textile Industry," Journal of Fashion Mar- 
keting and Management, 13(1), 20-36.

Sardy, Marc and Fetscherin, Marc. (2009), "A

Double Diamond Comparison of the Automotive Industry of China, India, and South Korea," Competition Forum, 7(1), 6-16.

Shin, Jae-Yong and Chun, Tae-Yoo. (2002), "A Study of the Case of the R\&D of the Apparel Industry," Journal of Fashion Business, 6(5), 112-124.

Son, Mi Young, Kim, Young Ju and Ji HyeKyung. (2007), "Utilizing of the Chinese Fashion Market for Globalization of Korean Fashion Industry: Focused on the Competitiveness of Korean and Chinese Fashion Industry by Applying the Double Diamond Model," Journal of the Korean Society of Clothing and Textiles, 31(4), 507-518.

Wyk, Jay V. (2010), “Double Diamonds, Real

Diamonds: Botswana’s National Competitiveness," Academy of Marketing Studies Journal, 14(2), 55-76.

Yeu Minsun, Lee Doo Hee, Yeo Jun Sang and Lee Hyun Joung. (2012), "A Case Study on Global Marketing of CJ O Shopping," Asia Marketing Journal, 13(4), 253- 264.

〈Web search〉

International Monetary Fund. "Gross Domestic Product (GDP)." http://www.imforg/external/ pubs/ft/weo/2010/02/weodata/weoselco.as px? $\mathrm{g}=2001 \& \mathrm{sg}=$ All + countries $($ accessed 4 March 2012)

International journal of clothing science and technology. http://search.proquest.com/ publication/29796 (accessed 7 March 2012) Japan Chemical Fibers Association. "Number of Workers and Laborers in the Clothing and Textile Industry (Japan)." http:// www.jcfa.gr.jp/english/tcij/1_textile_indu stry/1-1_structure.html (accessed 24 March 2012)

Japan Statistic Bureau. "Indices of Industrial Production (Preliminary Report) (2012, 1)." Research and Statistics Department Ministry of Economy, Trade and Industry, 24(1). http://www.meti.go.jp/statistics/tyo/iip/re sult/pdf/press/h2a1001j.pdf (accessed 14 March 2012)

Journal of fashion marketing and management. http://search.proquest.com/publication/272 51 (accessed 7 March 2012)

KIET(Korea Institute for Industrial Economics and Technology). "Fundamental Analysis of the Textile Industry (2011, 4)."http:// www.kiet.re.kr/kiet_web/?sub_num $=69$ \&state $=$ view\&idx $=51$ (accessed 14 March 2012)

Korea Federation of Textile Industries. "Textile Industry Statistics (2011, 1/2)." Korea Federation of Textile Industries 25.http:// www.kofoti.or.kr/bbs/viewbody.php?code $=$ STATISTICS $\&$ page $=\&$ id $=40043 \&$ num ber $=40043 \&$ keyfield $=$ \&keyword $=$ \&categ ory $=\&$ BoardType $=\&$ admin $\quad$ (accessed 3 March 2012)

Korean Statistical Information Service, "The 
Rate of Expenditure on Clothing \&Textile Out of Gross Income (Korea)." http:// kosis.kr/abroad/abroad_01List.jsp (accessed 6 March 2012)

OECD (Organization for Economic Cooperation and Development). "Total Amount of Outgoing FDI from Korean Clothing and Textile Enterprises (Outward FDI)," http:// stats.oecd.org (accessed 9 March 2012)

OECD (Organization for Economic Cooperation and Development). "Total Amount of Incoming FDI to Korean Clothing and Textile Industry(Inward FDI)." http:// stats.oecd.org (accessed 9 March 2012)

OECD (Organization for Economic Cooperation and Development). "Number of Total Population." http://stats,oecd,org (accessed 2 March 2012)

OECD (Organization for Economic Cooperation and Development). "Unemployment Rate." http://stats.oecd.org (accessed 2 March 2012)

Samsung Design Net. "'An Analysis of Fashion Market 2011/2012" http://www.samsungdesign. net/Market/MarketReport/content.asp?an $=64$ (accessed 7 March 2012)

Samsung Design Net. "The Impact of the Earthquake in Japan's Fashion Industry." http://www.samsungdesign.net (accessed 11 April 2012)

Statistics Bureau. "The Rate of Expenditure on Clothing \&Textile Out of Gross Income (Japan)." http://www.stat.go.jp/english/ data/kakei/156n.htm (accessed 6 March 2012)

The American Fiber Manufacturers Association. "Global Fibre Production: China and India Witness Expansion in Production of Polyester (2011,1,28)." Fiber Organon 26(2).http:// www.srtepc.org/pdfdoc/1_280111.pdf (accessed 16 March 2012)

UNCTAD (United Nations Conference on Trade and Development). "Increase in Rate of Exports (SITC 26+65+84)." http:// unctadstat.unctad.org/ReportFolders/report Folders,aspx (accessed 5 March 2012)

UNCTAD (United Nations Conference on Trade and Development). "The Rate of Clothing \&Textile Exports Out of Total Exports (SITC 26+65+84)." http://unctadstat.unctad. ag/ReportFolders/reportFolders.aspx (accessed 5 March 2012)

UNcomtrade (United Nations Commodity Trade Statistics Database). "Amount of Clothing \&Textile Exports." http://comtrade.un.org/ db/dqBasicQuery.aspx (accessed 30 March 2012)

World Bank. "Researcher in R\&D," http:// data.worldbank.org/indicator/SP.POP.SCIE .RD.P6 (accessed 5 March 2012)

World Bank. "R\&D Expenditure." http:// data.worldbank.org/indicator/GB.XPD.RSD V.GD.ZS (accessed 5 March 2012)

World Bank. "Royalty and License Fees, Receipts." http://data, worldbank,org/indicator/ BX.GSR.ROYL.CD (accessed 5 March 2012) 
World Bank. "Roads, Paved." http://data. worldbank.org/indicator/IS.ROD.PAVE.ZS (accessed 5 March 2012)

World Bank. "Rail Lines." http://data,worldbank. org/indicator/IS.RRS.TOTL.KM (accessed 5 March 2012)

World Bank. "Secure Internet Servers." http:// data.worldbank.org/indicator/IT.NET.SEC R.P6 (accessed 5 March 2012)
World Bank. "Fixed Broadband Internet Subscribers." http://data.worldbank.org/ indicator/IT.NET.BBND.P2 (accessed 5 March 2012)

World Bank. "Internet Users." http://data. worldbank.org/indicator/IT.NET.USER.P2 (accessed 5 March 2012)

World Trade Organization, "WTO International Trade Statistics (2010)." http://www.wto. org/english/res_e/statis_e/its2010_e/its1 0_toc_ehtm (accessed 2 April 2012) 